\title{
ANALISIS EKONOMI KAWASAN WISATA TAMAN NASIONAL GUNUNG GEDE PANGRANGO KECAMATAN CIPANAS KABUPATEN CIANJUR
}

\author{
James Sinurat ${ }^{1}$ \\ Staf Pengajar Program Pascasarjana Universitas Nusa Bangsa \\ Dewi Fitrianti \\ Kepala Tata Usaha Fakultas Kehutanan Universitas Nusa Bangsa
}

\begin{abstract}
The objectives of this research are: (1) To know the contribution of the National Park of Pangrango Gede Mountain to the people's income of Cimacan Village, District Cipanas, Cianjur Regency; (2) To know the contribution of infrastructure and facilities of the National Park of Pangrango Gede Mountain to the people's income of Cimacan Village, District Cipanas, Cianjur Regency; and (3) To know the contribution of promotion of the National Park of Pangrango Gede Mountain to the people's income of Cimacan Village, District Cipanas, Cianjur Regency. Data analysis methods used are: 1) Analysis data test (normality, multicolinearity, heteroskedasticity and autocorrelation); 2) Test regression and correlation using SPSS to see the effect of attraction management of the Natonal Park of Pangrango Gede Mountain against people's income of Cimacan Village, District Cipanas, Cianjur Regency. The results showed that: 1) The attractions of the Natonal Park of Pangrango Gede Mountain has significant effect on public revenues of Cimacan Village, District Cipanas, Cianjur Regency; 2) Infrastructure and facilities of the National Park of Pangrango Gede Mountain have significant effect on people's income of Cimacan Village, District Cipanas, Cianjur Regency; 3) Promotion of attraction management of the National Park of Pangrango Gede Mountain has real impact on people's income of Cimacan Village, District Cipanas, Cianjur Regency.

Keywords: People's Income, Infrastructure and Facilities, and Promotion of Tourism Object
\end{abstract}

\begin{abstract}
ABSTRAK
Penelitian ini bertujuan: (1) Untuk mengetahui kontribusi objek wisata TNGGP terhadap pendapatan masyarakat Desa Cimacan, Kecamatan Cipanas Kabupaten Cianjur; (2) Untuk mengetahui kontribuasi sarana dan prasarana TNGGP terhadap pendapatan masyarakat Desa Cimacan, Kecamatan Cipanas Kabupaten Cianjur; dan (3) Untuk mengetahui kontribusi promosi terhadap pendapatan masyarakat Desa Cimacan, Kecamatan Cipanas Kabupaten Cianjur. Metode analisis data yang digunakan adalah: 1) Analisis uji data (normalitas, multikolinieritas, heteroskedastisitas dan autokorelasi); 2) Uji regresi dan korelasi dengan menggunakan program SPSS untuk melihat pengaruh pengelolaan objek wisata Taman Nasional Gunung Gede Pangrango terhadap pendapatan masyarakat Desa Cimacan, Kecamatan Cipanas Kabupaten Cianjur. Hasil penelitian menunjukkan bahwa: 1) Objek wisata TNGGP berpengaruh nyata terhadap pendapatan masyarakat Desa Cimacan, Kecamatan Cipanas, Kabupaten Cianjur; 2) Prasarana dan sarana pada objek wisata Taman Nasional Gunung Gede Pangrango berpengaruh nyata terhadap pendapatan masyarakat di Desa Cimacan, Kecamatan Cipanas, Kabupaten Cianjur; 3) Promosi dari pengelolaan objek wisata Taman Nasional Gunung Gede Pangrango berpengaruh nyata terhadap pendapatan masyarakat Desa Cimacan, Kecamatan Cipanas, Kabupaten Cianjur.
\end{abstract}

Kata kunci: Pendapatan Masyarakat, Sarana dan Prasarana, dan Promosi Objek Wisata

${ }^{1}$ Email korespondensi: sinurat.james@gmail.com

JIMFE (Jurnal Ilmiah Manajemen Fakultas Ekonomi)

Volume 2 No. 2 Tahun 2016, Hal. 1-16 


\section{PENDAHULUAN}

\section{Latar Belakang}

Pariwisata adalah sektor yang dapat mendorong pertumbuhan ekonomi suatu wilayah. Pariwisata adalah aset yang strategis dalam mendorong pembangunan pada wilayah-wilayah tertentu yang mempunyai potensi objek wisata. Dengan adanya perkembangan industri pariwisata di suatu wilayah, maka arus urbanisasi ke kotakota besar dapat ditekan.

Selain peran yang dimilikinya, pariwisata juga merupakan suatu sektor yang tidak jauh berbeda dengan sektor ekonomi yang lain yaitu dalam proses perkembangannya berpengaruh terhadap bidang sosial dan ekonomi. Pengaruh yang ditimbulkan tersebut dapat berupa pengaruh positif maupun negatif terhadap kehidupan masyarakat setempat. Untuk mencegah perubahaan yang menuju ke arah negatif maka diperlukan suatu perencanaan yang mencakup aspek sosial dan ekonomi, sehingga sedapat mungkin masyarakat setempat ikut terlibat di dalam perencanaan dan pengembangan pariwisata. Hal ini perlu dilakukan upaya untuk mendukung keberhasilan pengembangan pariwisata daerah wisata yang bersangkutan (Kodhyat, 1996).

Pembangunan suatu wilayah dapat ditunjang oleh potensi wisata yang dimilikinya. Demikian juga dengan salah satu daerah tujuan wisata yang terdapat di Desa Cimacan, Kecamatan Cipanas, Kabupaten Cianjur yaitu kawasan wisata Taman Nasional Gunug Gede Pangrango (TNGGP), yang mempunyai potensi yang cukup tinggi dalam memberikan kontribusi terhadap pendapatan wilayah dan peningkatan Produk Domestik Regional Bruto (PDRB) Kabupaten Cianjur.

TNGGP adalah salah satu taman nasional terbaik di Indonesia karena memiliki keanekaragaman flora dan fauna yang bernilai tinggi. Kawasan ini meliputi tiga kabupaten di wilayah Provinsi Jawa Barat yaitu Kabupaten Cianjur, Kabupaten Bogor dan Kabupaten Sukabumi, sangat potensial untuk dikembangkan daerah wisata yang berbasis pada alam dan budaya. Oleh karena itu usaha pariwisata yang dikembangkan di daerah ini haruslah suatu usaha Green Industries, yaitu suatu usaha yang ditujukan untuk peningkatan kehidupan ekonomi masyarakat, perlindungan sumberdaya alam sebagai suatu aset ekonomi dan obyek wisata, serta sekaligus memperkuat sendisendi sosial budaya masyarakat melalui usaha berkelanjutan didukung oleh penerapan teknologi yang ramah lingkungan.

Dengan kondisi tersebut maka kawasan TNGGP semakin dipacu untuk meningkatkan kualitas kawasan dengan pembangunan dan perbaikan sarana serta prasarana penunjang wisata dengan tujuan agar jumlah wisatawan yang berkunjung ke TNGGP semakin meningkat dari waktu ke waktu. Adanya peningkatan kunjungan wisatawan dan aktivitas pariwisata yang berlangsung di dalam kawasan secara tidak langsung akan menimbulkan pengaruh terhadap kehidupan sosial dan masyarakat sekitar TNGGP.

Selain berpengaruh terhadap aspek sosial, kegiatan pariwisata juga berpengaruh terhadap aspek ekonomi yaitu terbukanya peluang atau kesempatan kerja atau usaha di dalam kawasan maupun di sekitar kawasan yang dapat meningkatkan pendapatan masyarakat setempat. $\mathrm{Hal}$ tersebut sesuai juga dengan Spilene (1987), yang mengatakan bahwa pariwisata akan membawa berbagai hal yang menguntungkan dan sekaligus merugikan. Walaupun sebenarnya tujuan pemerintah memajukan suatu daerah wisata adalah untuk kemakmuran dan peningkatan pendapatan masyarakat setempat.

\section{Perumusan Masalah}

Berdasarkan latar belakang di atas, maka dapat dirumuskan permasalahan dalam penelitian ini adalah sebagai berikut: 
1. Apakah objek TNGGP berkontribusi terhadap pendapatan masyarakat Desa Cimacan, Kecamatan Cipanas Kabupaten Cianjur?

2. Apakah sarana dan prasarana TNGGP berkontribusi terhadap pendapatan masyarakat Desa Cimacan, Kecamatan Cipanas Kabupaten Cianjur?

3. Apakah promosi berpengaruh terhadap pendapatan masyarakat Desa Cimacan, Kecamatan Cipanas Kabupaten Cianjur?

\section{Tujuan Penelitian}

Sesuai dengan rumusan masalah di atas, maka tujuan penelitian ini adalah sebagai berikut:

1. Untuk mengetahui kontribusi objek wisata TNGGP terhadap pendapatan masyarakat Desa Cimacan, Kecamatan Cipanas Kabupaten Cianjur.

2. Untuk mengetahui kontribuasi sarana dan prasarana TNGGP terhadap pendapatan masyarakat Desa Cimacan, Kecamatan Cipanas Kabupaten Cianjur.

3. Untuk mengetahui kontribusi promosi terhadap pendapatan masyarakat Desa Cimacan, Kecamatan Cipanas Kabupaten Cianjur.

\section{Manfaat Penelitian}

Hasil penelitian ini dapat bermanfaat baik bagi masyarakat, pemerintah maupun pihak TNGGP, yaitu:

1. Bagi masyarakat, hasil penelitian ini dapat digunakan sebagai bahan masukan dalam melakukan kerjasama dengan pihak TNGGP maupun pelayanan terhadap pengunjung.

2. Bagi pemerintah dan pihak manajemen TNGGP, hasil penelitian ini dapat bermanfaat dalam upaya pemberdayaan dan pembinaan usaha terhadap masyarakat sekitar kawasan TNGGP, perbaikan sarana dan prasarana, penataan ruang kawasan wisata terhadap pengunjung TNGGP.

3. Bagi peneliti lain di waktu yang akan datang. Hasil penelitian ini dapat dijadikan sebagai bahan rujukan bagi peneliti lain di waktu yang dalam mengukur hubungan timbal balik antara keuntungan ekonomi TNGGP.

\section{LANDASAN TEORI \\ Tinjauan Pustaka \\ Pemahaman Ekonomi}

Sebagaimana diketahui, manusia mempunyai kebutuhan yang beraneka ragam, sedangkan barang-barang dan jasa yang tersedia untuk memenuhi kebutuhan tersebut terbatas jumlahnya sehingga munculah ilmu ekonomi. Pada dasarnya ilmu ekonomi mempelajari perihal pilihan dan keputusan yang dilakukan setiap orang dalam memobilisasi dan mengalokasikan sumber ekonomi yang jumlahnya terbatas terhadap alat pemuas kebutuhan manusia yang tidak terbatas (Saputra, 2013).

IImu ekonomi adalah suatu studi mengenai bagaimana orang-orang dan masyarakat membuat pilihan, dengan cara atau tanpa penggunaan uang, dengan menggunakan sumberdaya yang terbatas tetapi dapat digunakan dalam berbagai cara untuk menghasilkan berbagai jenis barang dan jasa serta mendistribusikannya untuk keperluan konsumsi sekarang dan di masa mendatang, kepada berbagai orang dan golongan masyarakat. IImu ekonomi menganalisis biaya dan keuntungan serta memperbaiki corak penggunaan sumber daya.

Berdasarkan definisi ilmu ekonomi di atas, dapat disimpulkan bahwa prinsip dasar yang melahirkan ekonomi adalah:

1. Kelangkaan (scarcity), dan

2. Pilihan (choice).

Untuk itu, ilmu ekonomi mencakup segala perilaku manusia dalam hubungannya dengan pemenuhan kebutuhan yang beraneka ragam, baik perilaku sebagai 
produsen, maupun perilaku sebagai konsumen.

Teori dasar dalam ilmu ekonomi dibedakan menjadi dua, yaitu teori ekonomi mikro yang membahas permasalahan bersifat parsial atau bagian kecil dari kegiatan pendapatan, dan teori ekonomi makro, yang membahas permasalahan ekonomi yang bersifat global atau menyeluruh.

\section{a) Perspektif ekonomi mikro}

Jika diperhatikan kegiatan di pasar tradisional, maka akan melihat perilaku penjual dan pembeli dalam melakukan transaksi. Mereka saling menawar harga untuk mendapatkan kesepakatan harga atas barang atau jasa yang mereka butuhkan. Dari transaksi yang terjadi di pasar tersebut, tanpa sadar telah terjadi penerapan tentang ilmu ekonomi mikro.

Untuk jelasnya, ekonomi mikro adalah ilmu yang mempelajari aktivitas-aktivitas pendapatan yang bersifat bagian kecil, yang memusatkan perhatiannya pada masalah bagaimana konsumen akan mengalokasikan pendapatannya yang terbatas terhadap berbagai macam barang dan jasa yang dibutuhkan untuk memperoleh kepuasan maksimum (Yuniasih, 2014).

Aktivitas unit-unit ekonomi yang dikaji dalam ekonomi mikro diantaranya sebagai berikut:

1. Mempelajari bagaimana perilaku seseorang sebagai konsumen, sebagai pemilik sumber-sumber ekonomi dan sebagai produsen.

2. Mempelajari bagaimana arus perputaran barang dan jasa mulai dari produsen sampai pada konsumen.

3. Mempelajari bagaimana harga-harga barang dan jasa itu dapat terbentuk.

4. Mempelajari bagaimana produsen dalam menentukan tingkat produksi agar tercapai keuntungan yang maksimum.
5. Mempelajari bagaimana konsumen atau rumah tangga mengalokasikan pendapatannya yang sangat terbatas untuk barang dan jasa yang dibutuhkan sehingga tercapai kepuasan maksimum.

Dalam teori ekonomi mikro menganggap bahwa faktor produksi (alam, tenaga kerja, modal, dan pengusaha) yang dimiliki oleh masyarakat sifatnya terbatas, sedangkan keinginan manusia tidak terbatas. Untuk itu masyarakat harus dapat memilih kegiatan ekonomi, yang meliputi kegiatan dalam memproduksi, menyalurkan, dan menggunakan barang maupun jasa.

\section{b) Perspektif ekonomi makro}

Ekonomi makro merupakan bagian dari ilmu ekonomi yang mempelajari mekanisme bekerjanya pendapatan secara keseluruhan. Dengan demikian hubungan kausal yang dipelajari dalam ekonomi makro, pada intinya adalah hubungan antar variabel ekonomi agregatif (secara keseluruhan), seperti tingkat pendapatan nasional, tingkat kesempatan kerja, pengeluaran konsumsi rumah tangga, saving (tabungan), investasi nasional, tingkat bunga, jumlah uang yang beredar, neraca pembayaran, stok kapital nasional, utang pemerintah, dan sebagainya.

Hubungan di antara variabel-variabel tersebut, dapat bersifat kausal (sebab akibat) dan bersifat fungsional (saling mempengaruhi). Bersifat hubungan kausal (sebab akibat), seperti hubungan antara jumlah uang beredar dengan laju inflasi, hubungan antara meningkatnya pengeluaran konsumsi pemerintah dengan menurunnya tingkat pengangguran, dan sebagainya. Sedangkan yang bersifat hubungan fungsional (saling mempengaruhi), seperti hubungan pendapatan dengan pengeluaran konsumsi dan investasi, hubungan antara pendapatan dengan pengeluaran konsumsi dan tabungan, dan sebagainya. Secara matematis hubungan fungsional tersebut dapat dirumuskan sebagai berikut: 


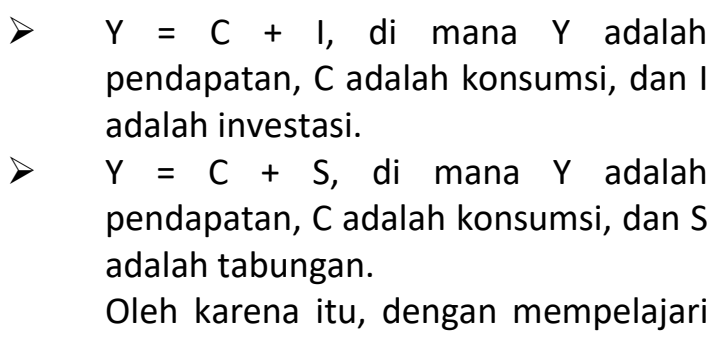
ekonomi makro seseorang akan menjadi lebih mampu untuk menyelesaikan masalahmasalah yang ada dalam suatu pendapatan. Adapun ekonomi makro menjelaskan tentang hal-hal berikut ini:

1. Pentingnya segi permintaan dalam menentukan tingkat kegiatan dalam pendapatan.

2. Pentingnya kebijakan dan campur tangan pemerintah untuk mewujudkan prestasi kegiatan ekonomi pada tingkat yang dikehendaki.

Selanjutnya, berdasarkan ruang lingkupnya menunjukkan bahwa teori ekonomi makro bertujuan memberikan gambaran tentang bagaimana suatu pendapatan berfungsi dan dapat menjalankan kegiatannya. Teori ekonomi makro bertitik tolak pada teori yang dikemukakan oleh ahli ekonomi yang bernama John Maynard Keynes, dalam bukunya yang berjudul The General Theory of Employment, Interest, and Money pada tahun 1936, yang secara garis besar dapat dibedakan menjadi dua aspek, yaitu:

1. Kritik atas pandangan ahli ekonomi klasik mengenai faktor-faktor yang menentukan tingkat kegiatan ekonomi suatu negara, dan

2. Pengeluaran agregat, yaitu pembelanjaan masyarakat atas barang dan jasa menjadi faktor utama yang menentukan tingkat kegiatan ekonomi suatu negara.

Secara ringkas ruang lingkup yang dipelajari dalam ilmu ekonomi makro meliputi hal-hal berikut ini:

1. Penghitungan pendapatan nasional.

2. Keseimbangan pendapatan nasional dalam pendapatan dua sektor.
3. Keseimbangan pendapatan nasional dalam pendapatan tiga sektor.

4. Kebijakan fiskal dan sistem perpajakan.

5. Uang bank, dan penciptaan uang.

6. Kebijakan moneter dan uang yang beredar.

7. Pasar uang dan pasar tenaga kerja.

8. Teori inflasi.

9. Perdagangan luar negeri, nilai valuta asing, dan neraca pembayaran.

10. Perdagangan luar negeri dan tingkat keseimbangan pendapatan nasional.

11. Pertumbuhan ekonomi dan pembangunan ekonomi.

\section{Perkembangan Pariwisata}

a) Pemahaman pariwisata

Pengertian pariwisata secara umum merupakan suatu perjalanan yang dilakukan seseorang untuk sementara waktu yang diselenggarakan dari suatu tempat ke tempat yang lain dengan meninggalkan tempat semula dan dengan suatu perencanaan atau bukan maksud untuk mencari nafkah di tempat yang dikunjunginya, tetapi semata-mata untuk menikmati kegiatan bertamasya atau rekreasi untuk memenuhi keinginan yang beraneka ragam.

Pariwisata didefinisikan sebagai perjalanan dari suatu tempat ke tempat lain, bersifat sementara, dilakukan perorangan maupun kelompok, sebagai usaha mencari keseimbangan atau keserasian atau kebahagiaan dengan lingkungan hidup dalam dimensi sosial, budaya, alam dan ilmu (http://eprints.ung.ac.id).

Berdasarkan pendapat maka dapat dikatakana bahwa pariwisata adalah suatu perjalanan yang dilakukan untuk sementara waktu dari satu tempat ke tempat lain yang mempunyai obyek dan daya tarik wisata untukdapat dinikmati sebagai suatu rekreasi atau hiburan yang mendapatkan kepuasan lahir dan batin. Sedangkan yang disebut wisatawan adalah orang yang mengadakan 
perjalanan dari tempat kediamannya tanpa menetap di tempat yang didatanginya, atau hanya untuk sementara waktu tinggal di tempat yang didatanginya.

\section{b) Pengembangan pariwisata}

\section{Menurut Paturusi}

(2001) pengembangan adalah suatu strategi yang dipergunakan untuk memajukan, memperbaiki dan meningkatkan kondisi kepariwisataan suatu objek dan daya tarik wisata sehingga dapat dikunjungi wisatawan serta mampu memberikan manfaat bagi masyarakat disekitar objek dan daya tarik wisata maupun bagi pemerintah.

Disamping itu pengembangan pariwisata bertujuan untuk memberikan keuntungan bagi wisatawan maupun masyarakat setempat. Dengan adanya pembangunan pariwisata diharapkan mampu meningkatkan taraf masyarakat melalui keuntungan secara ekonomi yang dibawa ke kawasan tersebut. Dengan kata lain pengembangan pariwisata melalui penyediaan fasilitas infrastruktur, wisatawan dan penduduk setempat akan saling diuntungkan. Pengembangan tersebut hendaknya sangat memperhatikan berbagai aspek, seperti aspek budaya, sejarah dan ekonomi daerah tujuan wisata.

Berdasarkan pengertian diatas, maka pengembangan pariwisata adalah suatu kegiatan menata dan memajukan suatu obyek wisata untuk dikembangkan menjadi lebih layak.

1) Pengertian Pengembangan Daya Tarik Wista (DTW)

Ismayanti (2010) memaparkan bahwa daya tarik objek wisata merupakan faktor utama penggerak pariwisata di sebuah destinasi. Dalam arti, daya tarik objek wisata sebagai penggerak utama yang memotivasi wisatawan untuk mengunjungi suatu tempat. Potensi daya tarik wisata memiliki beberapa tujuan diantaranya: (a) memperoleh keuntungan baik dari segi ekonomi berupa devisa negara dan pertumbuhan ekonomi serta dari segi sosial berupa peningkatan kesejahteraan rakyat dan menghapuskan kemiskinan, b) menghapuskan kemiskinan dengan pembukaan lapangan pekerjaan dan mengatasi pengangguran, (c) memenuhi kebutuhan rekreasi masyarakat, sekaligus mengangkat citra bangsa dan memperkukuh jati diri bangsa, memupuk rasa cinta tanah air melalui pengusahaan daya tarik dalam negeri, (d) melestarikan alam, lingkungan dan sumberdaya, sekaligus memajukan kebudayaan melalui pemasaran pariwisata, (e) mempererat persahabatan antar bangsa dengan memahami nilai agama, adat istiadat dan kehidupan masyarakat.

2) Pengertian Pengembangan Obyek Wisata

Segala sesuatu yang menarik dan bernilai untuk dikunjungi dan dilihat disebut "atraksi" atau lazim pula di katakan obyek wisata. Atraksi-atraksi ini antara lain panorama keindahan alam yang menakjubkan seperti gunung, lembah, ngarai, air terjun, danau, pantai, matahari terbit, dan matahari terbenam, cuaca, udara dan lain-lain. Di samping itu juga berupa budaya hasil ciptaan manusia seperti monumen, candi, bangunan klasik, peninggalan purbakala, musium budaya, arsitektur kuno, seni tari, musik, agama, adat-istiadat, upacara, pekan raya, peringatan perayaan hari jadi, pertandingan, atau kegiatan-kegiatan budaya, sosial dan keolahragaan lainnya yang bersifat khusus, menonjol dan meriah (Pendit, 2002).

Pengembangan obyek wisata alam sangat erat kaitannya dengan peningkatan produktifitas sumber daya alam dalam konteks pembangunan ekonomi, sehingga selalu dihadapkan pada kondisi interaksi berbagai kepentingan yang melibatkan aspek kawasan hutan, pemerintah daerah, aspek masyarakat, dan pihak swasta di dalam suatu sistem tata ruang wilayah. Kendala pengembangan obyek wisata alam berkaitan erat dengan: (a) Instrumen kebijaksanaan 
dalam pemanfaatan dan pengembangan fungsi kawasan untuk mendukung potensi obyek wisata alam, (b) Efektifitas fungsi dan peran obyekwisata alam ditinjau dari aspek koordinasi instansi terkait, (c) Kapasitas institusi dan kemampuan SDM dalam pengelolaan obyek wisata alam di kawasan hutan, dan (d) Mekanisme peran serta masyarakat dalam pengembangan pariwisata alam.

3) Perencanaan Pengembangan

Menurut Noer (2011), aspek perencanaan pengembangan obyek wisata alam mencakup sistem perencanaan kawasan, penataan ruang (tata ruang wilayah), standarisasi, identifikasi potensi, koordinasi lintas sektoral, pendanaan, dan sistem informasi obyek wisata alam.

a. Aspek kelembagaan meliputi pemanfaatan dan peningkatan kapasitas institusi, sebagai mekanisme yang dapat mengatur berbagai kepentingan, secara operasional merupakan organisasi dengan SDM dan peraturan yang sesuai dan memiliki efisiensi tinggi.

b. Aspeksarana dan prasarana yang memiliki dua sisi kepentingan, yaitu (1) alat memenuhi kebutuhan pariwisata alam, (2) sebagai pengendalian dalam rangka memelihara keseimbangan lingkungan, pembangunan sarana dan prasarana dapat meningkatkan daya dukung sehingga upaya pemanfaatan dapat dilakukan secara optimal.

c. Aspek pengelolaan, yaitu dengan mengembangkan profesionalisme dan pola pengelolaan obyek wisata alam yang siap mendukung kegiatan pariwisata alam dan mampu memanfaatkan potensi obyek wisata alam secara lestari.

d. Aspek pengusahaan yang memberi kesempatan dalam mengatur pemanfaatan obyek wisata alam untuk tujuan pariwisata yang bersifat komersial kepada pihak ketiga dan membuka lapangan kerja bagi masyarakat setempat.

e. Aspek pemasaran dengan mempergunakan teknologi tinggi dan bekerja sama dengan berbagai pihak baik dalam negeri maupun luar negeri.

f. Aspek peran serta masyarakat melalui kesempatan-kesempatan usaha sehingga ikut membantu meningkatkan kesejahteraan masyarakat.

g. Aspek penelitian dan pengembangan yang meliputi aspek fisik lingkungan, dan sosial ekonomi dari obyek wisata alam. Diharapkan nantinya mampu menyediakan informasi bagi pengembangan dan pembangunan kawasan, kebijaksanaan dan arahan pemanfaatan obyek wisata alam.

Dalam rangka mengembangkan obyek wisata perlu segera dilaksanakan inventarisasi terhadap potensi nasional obyek wisata alam secara bertahap sesuai prioritas dengan memperhatikan nilai keunggulan saing dan keunggulan banding, kekhasan obyek, kebijaksanaan pengembangan serta ketersediaan dana dan tenaga. Potensi daerah obyek wisata alam yang sudah ditemukan segera diinformasikan dan dipromosikan kepada calon penanam modal. Perlu dikembangkan sistem kemitraan dengan pihak swasta, lembaga swadaya masyarakat yang ada, dalam rangka mendukung optimalisasi pengembangan obyek wisata alam. Peranan Pemerintah Daerah dalam pengembangan obyek wisata alam sangat penting, dengan melaksanakan koordinasi, perencanaan, pelaksanaan serta monitoring pengembangan obyek wisata alam.

\section{c) Konsep wisata alam}

Pengertian tentang wisata alam mengalami perkembangan dari waktu ke waktu. Namun pada hakekatnya, pengertian ekowisata adalah suatu bentuk wisata yang 
bertanggung jawab terhadap kelestarian area yang masih alami, memberi manfaat secara ekonomi dan mempertahankan keutuhan budaya masyarakat setempat (Fandeli dan Mukhlison, 2000).

Berdasarkan pengertian diatas dapat disimpulkan bahwa wisata alam atau pariwisata ekologis adalah perjalanan ketempat-tempat alami yang relatif masih belum terganggu atau terkontaminasi (tercemari) dengan tujuan untuk mempelajari, mengagumi dan menikmati pemandangan, tumbuh-tumbuhan dan satwa liar, serta bentuk-bentuk manifestasi budaya masyarakat yang ada baik dari masa lampau maupun masa kini.

\section{Strategi Pengembangan Pariwisata Indonesia}

Strategi pada prinsipnya berkaitan dengan persoalan kebijakan pelaksanaan, penentuan tujuan yang hendak dicapai, dan penentuan cara-cara atau metode penggunaan sarana-prasarana. Strategi selalu berkaitan dengan tiga hal yaitu tujuan, sarana, dan cara. Oleh karena itu, strategi juga harus didukung oleh kemampuan untuk mengantisipasi kesempatan yang ada. Dalam melaksanakan fungsi dan peranannya dalam pengembangan pariwisata daerah, pemerintah daerah harus melakukan berbagai upaya dalam pengembangan sarana dan prasarana pariwisata (Yoeti, 1997).

Strategi perkembangan pariwisata yang menunjang pertumbuhan ekonomi dapat dilakukan dengan memperhatikan beberapa hal sebagai berikut:

a) Perlu ditetapkan beberapa peraturan yang berpihak pada peningkatan mutu pelayanan pariwisata dan kelestarian lingkungan wisata, bukan berpihak pada kepentingan pihak-pihak tertentu.

b) Pengelola pariwisata harus melibatkan masyarakat setempat. Hal ini merupakan hal penting karena sebagai hal pengalaman pada beberapa daerah tujuan wisata, apabila tidak melibatkan masyarakat setempat, akibatnya tidak ada sumbangsih ekonomi yang diperoleh masyarakat sekitar.

c) Kegiatan promosi harus beraneka ragam, selain dengan mencanangkan cara kampanye dan program "Visit Indonesia Year" seperti yang sudah dilakukan sebelumnya. Kegiatan promosi juga perlu dilakukan dengan membentuk sistem informasi yang handal dan membangun kerjasama yang baik dengan pusat informasi pada negara-negara lain terutama pada negara yang berpotensi.

d) Perlu menentukan daerah tujuan wisata yang memiliki keunikan dibanding dengan daerah tujuan wisata lain, terutama yang bersifat tradisional dan alami. Karena era kekinian-lah objek wisata yang alami dan tradisional yang menjadi sasaran wisatawan asing. Daerah ini masih banyak ditemukan di daerah luar jawa seperti daerah pedalaman Papua atau Kalimantan.

e) Pemerintah Pusat membangun kerjasama dengan kalangan swasta dan pemerintah daerah setempat, dengan sistem terbuka, jujur dan adil. Kerjasama ini penting karena untuk mempelancar pengelolaan secara profesional dengan mutu pelayanan yang memadai.

f) Perlu dilakukan pemerataan arus wisatawan bagi semua daerah tujuan wisata yang ada di seluruh Indonesia.

g) Mengajak masyarakat sekitar daerah tujuan wisata agar menyadari peran, fungsi dan manfaat pariwisata serta merangsang mereka untuk memanfaatkan peluang-peluang yang tercipta bagi berbagai kegiatan yang dapat menguntungkan secara ekonomi. 
h) Sarana dan prasarana yang dibutuhkan perlu dipersiapkan secara baik untuk menunjang kelancaran pariwisata, misalnya dengan pengadaan perbaikan jalan, telepon, internet dan pusat pembelanjaan di sekitar lokasi daerah wisata.

2. Faktor Pendorong Perkembangan Pariwisata Indonesia

Dewasa ini maupun pada masa yang akan datang, kebutuhan untuk berwisata akan meningkat khususnya di Indonesia seiring dengan bertambahnya jumlah penduduk dan meningkatnya kesejahteraan masyarakat. Serta perkembangan penduduk Indonesia yang semakin membutuhkan refreshing akibat semakin tingginya kesibukan kerja. Menurut Fandeli (1995), faktor yang mendorong manusia untuk berwisata ialah:

a) Keinginan untuk melepaskan diri dari tekanan hidup sehari-hari di kota, keinginan untuk mencari suasana baru untuk mengisi waktu lenggang.

b) Kemajuan pembangunan dalam bidang komunikasi dan transformasi.

c) Keinginan untuk melihat dan memperoleh pengalaman baru mengenai budaya masyarakat di tempat lainnya.

d) Meningkatnya pendapatan yang dapat memungkinkan seseorang dapat dengan bebas melakukan perjalanan yang jauh dari tempat tinggalnya.

Sedangkan faktor pendorong perkembangan pariwisata di Indonesia menurut Spilane (1987), adalah:

a) Berkurangnya peranan minyak bumi sebagai sumber devisa negara jika dibandingkan dengan waktu lalu.

b) Merosotnya nilai ekspor pada sektor nonmigas.

c) Adanya kecenderungan peningkatan pariwisata secara konsisten.

d) Besarnya potensi yang dimiliki oleh bangsa Indonesia bagi pengembangan pariwisata.
Ini semua memperlihatkan bahwa situasi dan kondisi sosial-ekonomi di Indonesia semakin berkurangnya lahan pertanian dan lapangan kerja lainnya serta semakin rusaknya lingkungan akibat kegiatan industri manufaktur dan kegiatan ekonomi lainnya yang mengeksploitasi sumber daya alam.

Pariwisata perlu dikembangkan sebagai salah satu pemasukan bagi devisa negara dan menjadi sumber industri andalan. Sektor pariwisata selain dapat meningkatkan pertumbuhan ekonomi, juga dapat merusak lingkungan bahkan sebaliknya merangsang pelestarian lingkungan hidup. Hal ini dapat dimaklumi karena perkembangan pariwisata tidak dapat dipisahkan dari lingkungan hidup sebagai salah satu sarana atau objek wisata.

\section{Kerangka Pemikiran}

Sesuai dengan tujuan pengelolaan TNGGP yang dimanfaatkan untuk tujuan penelitian, ilmu pengetahuan, menunjang budidaya, pariwisata dan rekreasi, maka dalam penelitian ini lebih menyoroti pada permasalahan pariwisata dan rekreasi, yang menjadi sumber dalam meningkatkan pendapatan wilayah Kabupaten Cianjur khususnya masyarakat Desa Cimacan dimana TNGGP berada. Kegiatan wisata yang dilakukan oleh pengunjung TNGGP bisa berupa kegiatan pendakian gunung, hiking, tracking, dan berkemah.

Oleh karena itu, pengendalian jumlah pengunjung di TNGGP merupakan salah satu jalan untuk menjaga keseimbangan daya dukung lingkungan kawasan guna tercapainya kelestarian baik secara ekologi maupun secara ekonomi.

Penelitian ini dilatarbelakangi oleh suatu pemikiran bahwa keberadaan TNGGP memberikan dampak positif terhadap pendapatan masyarakat Desa Cimacan, Kecamatan Cimacan, Kabupaten Cianjur yang berada di sekitar kawasan. Oleh karena itu, untuk memastikan dampak positif 
tersebut perlu dilakukan penelitian yang lebih mendalam mengenai hal tersebut. Untuk menunjang lancarnya penelitian ini, dilakukan pengumpulan data pendapatan masyarakat Desa Cimacan yang berada di sekitar kawasan TNGGP tersebut.

\section{Hipotesis}

Dalam penelitian ini dikemukakan hipotesis sebagaimana berikut:

1. TNGGP berpengaruh terhadap pendapatan masyarakat Desa Cimacan, Kecamatan Cipanas Kabupaten Cianjur.

2. Prasarana dan sarana TNGGP berpengaruh terhadap pendapatan masyarakat Desa Cimacan, Kecamatan Cipanas, Kabupaten Cianjur.

3. Promosi berpengaruh terhadap pendapatan masyarakat Desa Cimacan, Kecamatan Cipanas Kabupaten Cianjur.

\section{METODOLOGI PENELITIAN}

Metode yang digunakan dalam penelitianini adalah kuantitatif deskriptif dengan menggunakan data sekunder. Hasil penelitian kuantitatif dideskripsikan dengan mempelajari berbagai aspek yang mendorong untuk melakukan penelitian yang merupakan refleksi dari keinginan manusia yang selalu berusaha untuk mengetahui sesuatu. Keinginan untuk memperoleh dan mengembangkan pengetahuan merupakan kebutuhan dasar manusia yang umumnya menjadi motivasi untuk melakukan penelitian (Sugiyono, 2003).

\section{Disain Penelitian}

Desain penelitian adalah pedoman atau prosedur serta teknik dalam perencanaan penelitian yang berguna sebagai panduan untuk membangun strategi yang menghasilkan model atau blue print penelitian (Hasibuan, 2007).
Desain penelitian ini harus memuat segala sesuatu yang berkaitan dengan pelaksanaan penelitian yang akan dilakukan. Sifat desain penelitian mendekati komprehensif dari keseluruhan kerja penelitian, maka apabila peneliti telah siap dengan desain penelitian berarti separuh kerja penelitiannya telah selesai (Bungin, 2001).

\section{Lokasi Penelitian}

Penelitian ini dilaksanakan di Desa Cimacan (sekitar kawasan TNGGP), Kecamatan Cipanas, Kabupaten Cianjur.

\section{Teknik Pengumpulan Data}

\section{Populasi dan Sampel}

Menurut Sugiyono (2003), populasi adalah wilayah generalisasi terdiri atas obyek/subyek yang mempunyai kualitas dan karakteristik tertentu, ditetapkan oleh peneliti untuk dipelajari dan kemudian ditarik kesimpulan. Sedangkan sampel adalah sebagian dari jumlah dan karakteristik yang dimiliki oleh populasi tersebut.

Menurut Arikunto (2008), penentuan pengambilan sampel sebagai berikut: apabila populasi kurang dari 100 lebih baik diambil semua hingga penelitiannya merupakan penelitian populasi. Jika jumlah subjeknya besar $(>100)$ dapat diambil antara 10-15\% atau $20-55 \%$ atau lebih, tergantung dari:

1. Kemampuan peneliti dilihat dari waktu, tenaga dan dana.

2. Sempit luasnya wilayah pengamatan dari setiap subyek, karena hal ini menyangkut banyak sedikitnya waktu dan dana.

3. Besar kecilnya resiko yang ditanggung oleh peneliti untuk penelitian yang resikonya besar, tentu saja jika sampelnya besar hasilnya akan lebih baik.

Populasi dan sampel dalam penelitian ini adalah masyarakat Desa Cimacan yang berada di sekitar kawasan TNGGP yang 
terkena dampak dari kegiatan wisata TNGGP.

Adapun rumus yang dipakai dalam menentukan besar sampel adalah menggunakan rumus slovin menurut Riduwan (2011), yaitu:

$$
\mathrm{n}=\mathrm{N}_{\left(1+\mathrm{N} . \mathrm{d}^{2}\right)}^{\mathrm{N}}
$$

Keterangan:

$\mathrm{n}$ : ukuran sampel

$\mathrm{N}$ : ukuran populasi

d: tingkat kesalahan $5 \%=0,05$ (tingkat kepercayaan 95\%)

\section{Teknik Pengumpulan Data}

Dalam memenuhi kebutuhan data yang relevan dengan obyek penelitian, maka teknik yang digunakan adalah:

a. Wawancara. Teknik ini dilakukan untuk mengetahui persepsi masyarakat terhadap keberadaan TNGGP.

b. Kuesioner. Kuesioner adalah suatu teknik pengumpulan data dimana para responden diberikan sekumpulan pertanyaan yang harus dijawab. Penyebaran kuesioner disesuaikan dengan jumlah sampel yang telah dipilih.

c. Dokumentasi. Dokumentasi adalah suatu teknik pengumpulan data dengan cara mengutip kembali data yang telah tersedia yang diperlukan.

Dalam penelitian ini data primer diperoleh dari wawancara, kuesioner dan observasi. Penggunaan metode wawancara dan kuesioner bertujuan untuk menghimpun persepsi, informasi dan keterangan mengenai hal-hal yang diketahui atau yang di alami oleh responden. Sedangkan observasi dilakukan bertujuan untuk mengumpulkan data berdasarkan pengamatan langsung di lapangan.

Sedangkan untuk data sekunder digunakan teknik dokumentasi, yaitu dengan cara mengumpulkan, mempelajari dan mencatat dokumen/data yang telah tersedia yang berkaitan dengan penelitian yang sedang dilakukan.

Teknik Pengolahan dan Penyajian Data

Teknik pengolahan data yang digunakan adalah sebagai berikut:

1. Teknik perhitungan dengan matematika sederhana, yaitu mengolah data dengan menggunakan perhitungan statistik sederhana.

2. Metode deskriptif yaitu dengan memberikan gambaran tentang keadaan di lokasi penelitian.

Untuk penyajian data digunakan teknik sebagai berikut:

1. Data naratif yaitu menyajikan data ke dalam bentuk narasi digunakan untuk menyajikan data kualitatif.

2. Data tabel yaitu menyajikan data baik data numerik maupun data non numerik ke dalam tabel-tabel.

Untuk memudahkan dalam pengolahan data, peneliti menggunakan program Excel dan program SPSS.

\section{Metode Analisis}

Metode analisis yang digunakan dalam penelitian ini adalah analisis kualitatif deskriptif yang tujuannya adalah untuk mendeskripsikan suatu keadaan, objek apakah terkait dengan variabel-variebel yang bisa dijelaskan baik dengan angka-angka maupun kata-kata (Setyosari, 2010).

\section{HASIL DAN PEMBAHASAN}

\section{Hasil Penelitian}

\section{Gambaran Umum Lokasi Penelitian}

a. Letak geografis

TNGGP merupakan kawasan Taman Nasional yang ditutupi oleh hutan hujan tropis pegunungan dengan luas $22.851,03$ hektar, berjarak tempuh 2 jam atau 100 km dari Jakarta. Akses jalan menuju TNGGP melalui Desa Cimacan Kecamatan Cipanas Kabupaten Cianjur, sehingga masyarakat 
yang paling merasakan dampak keberadaan objek wisata tersebut adalah masyarakat Desa Cimacan.

Desa Cimacan merupakan bagian dari desa di Kecamatan Cipanas di Kabupaten Cianjur dengan luas wilayah $58,03 \mathrm{~km}^{2}$ dengan batas wilayah bagian utara Kabupaten Cianjur, bagian selatan Kecamatan Pacet, bagian timur Kecamatan Sukaresmi dan Pacet, bagian barat Kecamatan Cisarua. Jumlah penduduk Desa Cimacan 91.405 jiwa dengan kepadatan $1.575 \mathrm{jiwa} / \mathrm{km}^{2}$.

\section{b. Fasilitas yang tersedia}

TNGGP ditetapkan sebagai taman nasional pada tahun 1980-an oleh Menteri Pertanian yang ditetapkan dengan SK Menteri Pertanian No. 736/Mentan/X/1982. Saat ini TNGGP mempunyai wilayah seluas 22.851,03 ha.

TNGGP juga merupakan habitat dari berbagai jenis satwa liar, seperti kepik raksasa, sejenis kumbang, lebih dari 100 jenis mamalia seperti kijang, pelanduk, anjing hutan, macan tutul, sigung, serta 250 jenis burung.

TNGGP meliputi Cagar Alam Cibodas, Cagar Alam Cimungkat dan Taman Wisata Alam Situ Gunung. Menurut administrasi pemerintahan termasuk ke dalam tiga wilayah Kabupaten yaitu terdiri dari Kabupaten Cianjur, Kabupaten Bogor, dan Kabupaten Sukabumi.

Menurut klasifikasi iklim Scmidt dan Ferguson, tipe iklim di kawasan ini termasuk tipe iklim A. Rata-rata temperaturnya bervariasi antara $18^{\circ} \mathrm{C}$ di Cibodas dan kurang dari $10^{\circ} \mathrm{C}$ di puncak Gunung Pangrango.

\section{c. Potensi wisata alam TNGGP}

1. Telaga Biru terletak $\pm 1,5 \mathrm{~km}$ dari pintu masuk Cibodas.

2. Rawa Gayonggong terletak $\pm 1,8 \mathrm{~km}$ dari pintu masuk Cibodas.

3. Air terjun Cibeureum terletak $\pm 2,5 \mathrm{~km}$ dari pintu masuk Cibodas.
4. Air terjun Curug Sawer terletak $\pm 2 \mathrm{~km}$ dari pintu masuk taman wisata Alam Situ Gunung.

5. Air panas terletak $\pm 5,2 \mathrm{~km}$ dari pintu masuk Cibodas, di ketinggian 2.150 meter dpl.

6. Kawah Gunung Gede terletak $\pm 8,9$ km dari pintu masuk Cibodas.

7. Alun-alun Surya Kencana terletak pada ketinggian 2.750 meter, antara Gunung Gede dan Gunung Gumuruh, terdapat daerah datar dengan panjang 1.500 meter dan lebar 250 meter. Lokasi ini berjarak $\pm 10,2 \mathrm{~km}$ dari pintu masuk Cibodas dan $\pm 6,9 \mathrm{~km}$ dari pintu masuk Gunung Putri

8. Alun-alun Pangrango terletak di lereng Gunung Pangrango. Seperti alun-alun Surya Kencana, lapangan ini banyak ditumbuhi bunga edelwis akan tetapi luasnya lebih kecil dari pada alun-alun Surya Kencana.

9. Telaga Biru terletak $\pm 1,5 \mathrm{~km}$ dari pintu masuk Cibodas.

10. Rawa Gayonggong terletak $\pm 1,8 \mathrm{~km}$ dari pintu masuk Cibodas.

11. Air terjun Cibeureum terletak $\pm 2,5 \mathrm{~km}$ dari pintu masuk Cibodas.

12. Air terjun Curug Sawer terletak $\pm 2 \mathrm{~km}$ dari pintu masuk taman wisata Alam Situ Gunung.

13. Air panas terletak $\pm 5,2 \mathrm{~km}$ dari pintu masuk Cibodas pada ketinggian 2.150 meter dpl.

14. Kawah Gunung Gede terletak $\pm 8,9 \mathrm{~km}$ dari pintu masuk Cibodas.

15. Alun-alun Surya Kencana terletak pada ketinggian 2.750 meter, antara Gunung Gede dan Gunung Gumuruh, terdapat daerah datar dengan panjang 1.500 meter dan lebar 250 meter. Lokasi ini berjarak $\pm 10,2 \mathrm{~km}$ dari pintu masuk Cibodas dan $\pm 6,9 \mathrm{~km}$ dari pintu masuk Gunung Putri.

16. Alun-alun Pangrango terletak di lereng Gunung Pangrango. Seperti alun-alun Surya Kencana, lapangan ini banyak 
ditumbuhi bunga Edelwis akan tetapi luasnya lebih kecil dari pada alun-alun Surya Kencana.

\section{d. Karakteristik responden}

Dari hasil penelitian diketahui bahwa responden yang berusaha sebagai pedagang sebagian besar berusia 26-54 tahun adalah $82,8 \%$, diikuti oleh kelompok umur 17-25 tahun dan di atas 55 tahun. Menurut jenis kelamin didominasi oleh laki-laki yaitu ratarata $58,6 \%$, dan sisanya wanita.

Untuk pendidikan terakhir responden rata-rata terbanyak adalah SLTA sebanyak 45\% diikuti oleh SLTP dan SD serta S1 dan S2 sebanyak $25,3 \%, 21,8 \%, 2,3 \%$ dan $1,1 \%$. Jumlah tanggungan responden tertinggi adalah dengan jumlah tanggungan 2 orang, diikuti oleh 1 orang, 3 orang dan 4 orang, 5 orang dan 6 orang. Sebagian besar pekerjaan sampingan responden adalah bertani sebesar $44,8 \%$, pemandu wisata dan beternak $11 \%$. Untuk lama responden berdagang paling lama sekitar 3-5 tahun sebanyak $21,8 \%$, diikuti dengan $1-3$ tahun dan kurang dari 1 tahun sebesar $14,9 \%$ dan $9,2 \%$. Produk yang dijual terbanyak oleh responden adalah souvenir yaitu $47,1 \%$, diikuti oleh makanan/minuman dan alat camping sebanyak $41,4 \%$ dan 9,2\%, kemudian produk yang laku terjual adalah souvenir dengan rata-rata $42,5 \%$, diikuti oleh makanan/minuman dan alat camping sebesar $39,1 \%$ dan $10,3 \%$. Untuk modal awal tergolong masih rendah dimana modal awal responden tertinggi rata-rata hanya Rp1-3 juta sebanyak $26,4 \%$ diikuti oleh modal $\mathrm{Rp}$ 3-5 juta dan kurang dari Rp1 juta sebesar $25,3 \%$ dan $17,2 \%$ dengan keuntungan per bulan rata-rata kurang dari Rp1 juta sebanyak 52,9\% diikuti oleh Rp1 -3 juta dan Rp3 - 5 juta per bulan sebanyak 33,3\% dan $5,7 \%$ kemudian dan rata-rata waktu kedatangan pengunjung terbanyak adalah pada waktu libur hari raya sebesar $45 \%$ diikuti oleh musim libur sekolah sebesar 40,2\% dan libur Sabtu dan Minggu sebanyak
$8 \%$ dan libur akhir tahun 3,4\%. Pada umumnya para pedagang terbanyak berasal dari luar TNGGP yaitu sebanyak $79,3 \%$ dimana pada umumnya ditemukan berasal dari masyarakat ekonomi lemah terbukti dari rata-rata modal awal yang dimiliki untuk memulai usaha yang jumlahnya berkisar Rp1 -3 juta sebanyak $26,4 \%$.

\section{Analisis Data}

\section{a. Hasil Pengujian Validitas Instrumen} Penelitian

Pengujian validitas instrumen penelitian adalah untuk mengetahui setiap item kuesioner yang termasuk valid dan yang tidak termasuk valid. Pengertian valid adalah kuesioner efektif sebagai alat pengumpul data untuk menggali permasalahan yang dijadikan obyek penelitian. Pengukuran validitas instrumen penelitian dilakukan dengan menggunakan rumus koefisien product moment (product moment coefficient of correlation).

Untuk mengetahui koefisien validitas, penulis melakukan perhitungan dengan program statistik SPSS 15.0 for Windows. Dari hasil penghitungan terlihat bahwa salah satu item butir pertanyaan nomor 17 untuk variabel pengelolaan objek wisata TNGGP dinyatakan tidak valid karena adalah pertanyaaan nomor 17 yang nilai R-product moment-nya lebih kecil dari 0.5. Untuk itu dilakukan analisa ulang untuk validitas pada variabel pengelolaan objek wisata TNGGP.

Selanjutnya adalah hasil analisis validitas kuisioner untuk variabel pendapatan masyarakat (Y). Dari hasil penghitungan terlihat bahwa seluruh item butir pertanyaan nomor 37 dan 40 dinyatakan valid karena koefisien korelasinya berada di bawah 0,05.

\section{1) Hasil Pengujian Reliabilitas Alat Ukur \\ Pengujian reliabilitas alat ukur} dimaksudkan untuk mengukur apakah instrumen penelitian yang dipakai sebagai alat pengumpul data dapat 
dipercaya/diandalkan. Pengukuran reliabilitas alat ukur ini menggunakan teknik reliability analysis alpha yang dibantu dengan program SPSS 15.0 for Windows. Adapun hasil perhitungan yang diperoleh untuk masing-masing variabel $(X)$.

Hasil perhitungan nilai reliabilitas dari variabel pengelolaan objek wisata TNGGP $(X)$ didapatkan nilai Alpha Cronbach untuk variabel

Objek wisata bernilai 0,870, untuk variabel prasarana dan sarana adalah 0,988 , untuk variabel promosi dengan nilai 0,790 dan variabel pelayanan adalah sebesar 0,920 yang seluruhnya terletak di antara 0,79-1,00, sehingga tingkat reliabilitasnya sangat reliable. Hal ini membuktikan bahwa kuesioner yang digunakan untuk mengukur pengelolaan objek wisata TNGGP $(X)$ terbukti reliabel.

Nilai Reliabilitas untuk variabel pendapatan masyarakat $(\mathrm{Y})$ yang terdiri dari variabel pendapatan masyarakat dan lapangan kerja dengan nilai 0,893 dan variabel perkembangan aktifitas ekonomi dengan nilai 0,852 yang semuanya juga tergolong sangat reliable.

\section{Pembahasan}

\section{Objek Wisata TNGGP terhadap PendapatanMasyarakat Secara Parsial}

Dari hasil analisis regresi dan korelasi baik parsial maupun berganda atau serempak didapatkan bahwa apabila pengelolaan objek wisata ditingkatkan secara parsial baik dari faktor kualitas objek wisata $\left(X_{1}\right)$, prasarana dan sarana $\left(X_{2}\right)$, promosi $\left(X_{3}\right)$, maupun pelayanannya terhadap wisatawan $\left(\mathrm{X}_{4}\right)$ maka pengaruhnya tidak sebanyak apabila peningkatan pengelolaan dilakukan secara serentak atau berganda keseluruhan baik dari faktor objek wisatanya, dari faktor prasarana dan sarana, promosi maupun pelayanan. Hal ini terbukti dari hasil kontribusi atau R Square $\left(r^{2}\right)$ yang didapatkan dari masing-masing variabel pengaruhnya terhadap pendapatan masyarakat didapatkan kontribusi yang lebih tinggi.

Pengaruh pengelolaan yang tertinggi terhadap pendapatan masyarakat apabila dilihat dari masing-masing variabel adalah dari segi objek wisata $\left(X_{1}\right) 86,8 \%$ lalu diikuti oleh variable promosi $\left(X_{3}\right) 78,4 \%$, prasarana dan sarana $\left(X_{2}\right)$ sebesar $59,6 \%$ dan pelayanannya terhadap wisatawan $\left(X_{4}\right)$ sebesar $37,2 \%$. Begitu juga dengan besarnya hubungan antara pengelolaan objek wisata TNGGP $(X)$ terhadap pendapatan masyarakat $(\mathrm{Y})$, dimana prasarana dan sarana $\left(\mathrm{X}_{2}\right)$ yang paling erat hubungannya terhadap pendapatan masyarakat $(Y)$ yaitu dari objek wisata $\left(X_{1}\right)$ sebesar 0,931 , faktor promosi $\left(X_{3}\right)$, faktor prasarana dan sarana $\left(X_{2}\right)$ sebesar 0,772 diikuti oleh pelayanan terhadap wisatawan $\left(\mathrm{X}_{4}\right)$ sebesar 0,610 .

$\mathrm{Di}$ antara ke empat faktor ini yang paling besar pengaruhnya terhadap pendapatan masyarakat adalah objek wisata $\left(X_{1}\right)$, promosi $(X 3)$, prasarana dan sarana $\left(X_{2}\right)$ serta pelayanan $\left(X_{4}\right)$. Hal ini diduga karena pengelolaan TNGGP sudah sesuai dengan kondisi lingkungan alam dan masyarakat dan obyek pariwisata TNGGP dipengaruhi oleh iklim sekitar.

Hasil wawancara dengan responden memperlihatkan bahwa sebanyak $36,3 \%$ responden mengatakan kurang setuju serta $63,8 \%$ responden setuju bila dikatakan objek wisata TNGGP tidak dipengaruhi oleh iklim. Hal ini akan mengakibatkan pengunjung hanya bisa berkunjung pada musim tertentu (tidak musim penghujan), sehingga untuk meningkatkan pendapatan lokal maka faktor Objek. Begitu pula dengan pengelolaan TNGGP sudah sesuai dengn kondisi lingkungan alam dan masyarakat sekitar dan objek periwisata TNGGP sangat strategis untuk dikembangkan. Dan objek pariwisata TNGGP menyediakan lokasi kepada penduduk setempat untuk berdagang $33,8 \%$ kurang setuju dan $66,3 \%$ setuju. Hal ini terlihat di lapangan dimana lokasi yang 
disediakan untuk pedagang masih terlihat belum tertata rapi sehingga para pengunjung akan kesulitan untuk mencari keperluan yang akan dibeli selama berkunjung, dan akan kelihatan kurang indah bila belum tertata dengan rapi. Rata-rata menjawab tidak setuju 1,3\% dan kurang setuju 32,5\% dan setuju $66,3 \%$. Untuk itu pengelolaan TNGGP terutama objek wisata $\left(X_{1}\right)$ harus menjadi perhatian utama

Namun demikian dari seluruh kondisi objek wisata $\left(X_{1}\right)$ yang sangat membantu adalah keberadaan TNGGP sebagai obyek pariwisata dapat diterima masyarakat secara adat istiadat oleh masyarakat setempat, obyek TNGGP tidak akan mengganggu aktivitas masyarakat mencari nafkah dari pekerjaan utamanya, obyek pariwisata TNGGP menyediakan tempat (space) kepada penduduk setempat untuk berdagang. Hal ini terlihat dari pendapat responden yang mengatakan sangat setuju keberadaan TNGGP sebagai obyek pariwisata dapat diterima masyarakat secara adat istiadat oleh masyarakat setempat sebanyak $66,3 \%$.

Dari uraian di atas dapat disimpulkan bahwa apabila dilihat secara parsial maka faktor yang paling berperan dalam mempengaruhi pendapatan masyarakat $(Y)$ adalah faktor objek wisata $\left(X_{1}\right)$, faktor promosi $\left(\mathrm{X}_{3}\right)$. Serta prasarana dan sarana $\left(X_{2}\right)$ sedangkan yang paling sedikit pengaruhnya terhadap pendapatan masyarakat $(\mathrm{Y})$ adalah) dan pelayanan $\left(\mathrm{X}_{4}\right)$.

\section{Pengaruh Objek Wisata TNGGP terhadap Pendapatan Masyarakat Secara Serempak.}

Dari hasil wawancara tertulis didapatkan masukan dari responden yang menyatakan tidak setuju dengan pertanyaan yang menyatakan bahwa obyek pariwisata TNGGP tidak dipengaruhi oleh iklim, karena waktu kunjungan jadi terbatas sehingga mempengaruhi pendapatan masyarakat.

Dari uraian di atas disimpulkan bahwa untuk meningkatkan pendapatan masyarakat perlu ditingkatkan faktor objek wisata terutama pengelolaan TNGGP untuk menjaga lingkungan supaya tidak rusak dengan menertibkan lagi masalah jumlah pengunjung pada musim-musim tertentu dan menjaga lingkungan terutama sampah, sehingga lingkungan alam sekitar TNGGP tetap terjaga dengan baik.

\section{KESIMPULAN DAN SARAN}

\section{Kesimpulan}

1. Objek wisata TNGGP berkontribusi terhadap pendapatan masyarakat Desa Cimacan, Kecamatan Cipanas, Kabupaten Cianjur.

2. Sarana dan prasarana TNGGP berkontribusi terhadap pendapatan masyarakat di Desa Cimacan, Kecamatan Cipanas, Kabupaten Cianjur.

3. Promosi objek wisata TNGGP berkontribusi terhadap pendapatan masyarakat Desa Cimacan, Kecamatan Cipanas, Kabupaten Cianjur.

\section{Saran}

1. Dalam meningkatkan pendapatan masyarakat perlu ditingkatkan faktor objek wisata terutama pengelolaan TNGGP untuk menjaga lingkungan supaya tidak rusak dengan menertibkan lagi masalah jumlah pengunjung pada musim-musim tertentu dan menjaga lingkungan terutama sampah, sehingga lingkungan alam sekitar TNGGP tetap terjaga dengan baik.

2. Faktor promosi yang dilakukan juga harus sesuai dengan aturan yang berlaku untuk meningkatkan pendapatan masyarakat.

\section{DAFTAR PUSTAKA}

Arikunto, Suharsimi. 2008. Prosedur Penelitian, Suatu Pendekatan Praktek. Rineka Cipta. Jakarta. 
Bungin, Burhan. Analisis Data Penelitian Kualitatif. PT. Raja Grafindo Persada. Jakarta.

Fendeli, Chalid. 1995. Pengertian dan Kerangka Dasar Kepariwisataan. Liberty. Jakarta.

Fendeli, C dan Mukhlison. 2000. Pengusahaan Ekowisata. UGM. Yogyakarta.

Hasibuan, Zainal, A. 2007. Metodologi Penelitian Pada Bidang IImu Komputer dan Teknologi Informasi: Konsep, Teknik dan Aplikasi, Jakarta: Fakultas IImu Komputer Universitas Indonesia

http://eprints.ung.ac.id. Pengertian dan Konsep Pariwisata. Diakses pada 2 Juli 2015.

Ismayati. 2010. Pengantar Pariwisata. PT. Grasindo. Jakarta.

Kodhat.1996. Sejarah Pariwisata dan Perkembangannya di Indonesia. Gramedia Widiasarana Indonesia. Jakarta.www.goodreads diakses 17 Juli 2016.

Noer, M. 2011. Strategi Pengembangan Obyek Wisata, https://noerdblok.

Paturusi, Samsul A. 2011. Perencanaan Tata Ruang Kawasan Pariwisata. Materi Kuliah Perencanaan Kawasan Pariwisata. Program Pascasarjana Universitas Udayana Denpasar.

Pendit, S. 1990. Ilmu Pariwisata Sebuah Pengantar Perdana. Pradnya Paramita. Jakarta.

Riduwan.2009. Skala Pengukuran VariabelVariabel Penelitian. Penerbit Alfabeta. Bandung.

Setyosari, P. 2010. Metode Penelitian Pendidikan dan Pengembangan. Kencana. Jakarta.

Sugiyono. 2003. Metode Penelitian Administrasi. Penerbit Alfabeta. Bandung.

Spilene, James J. 1987. Pariwisata Indonesia, Sejarah dan Prospeknya. Kanisius. Yogyakarta.
Yoeti A.O. 1997. Perencanaan dan Pengembangan Pariwisata. Pradnya Paramita. Jakarta.

Surat Keputusan Menteri Pertanian No. 736/Mentan/X/1982 tanggal 10 Oktober 1982 tentang Taman Nasional.

Yuniasih E. 2014. Pengertian Ekonomi Mikro. Artikel Ilmu Ekonomi. Wikipedia Ensiklopedia Bebas. Di akses pada 1 Juli 2015. 